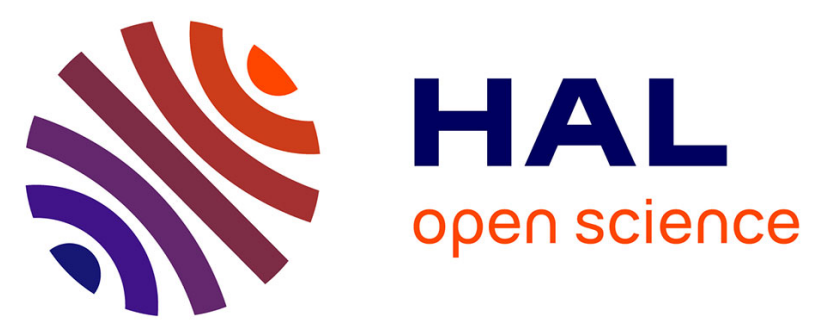

\title{
Detection of plasmid-mediated colistin resistance, mcr-1 gene, in Escherichia coli isolated from high-risk patients with acute leukemia in Spain
}

Rym Lalaoui, Ana Djukovic, Sofiane Bakour, Jaime Sanz, Eva

Gonzalez-Barbera, Miguel Salavert, Jose Luis López-Hontangas, Miguel Sanz, Karina Xavier, Bernhard Kuster, et al.

\section{To cite this version:}

Rym Lalaoui, Ana Djukovic, Sofiane Bakour, Jaime Sanz, Eva Gonzalez-Barbera, et al.. Detection of plasmid-mediated colistin resistance, mcr-1 gene, in Escherichia coli isolated from high-risk patients with acute leukemia in Spain. Journal of Infection and Chemotherapy, 2019, 25 (8), pp.605-609. 10.1016/j.jiac.2019.03.007 . hal-02262518

\section{HAL Id: hal-02262518 \\ https://hal-amu.archives-ouvertes.fr/hal-02262518}

Submitted on 25 Oct 2021

HAL is a multi-disciplinary open access archive for the deposit and dissemination of scientific research documents, whether they are published or not. The documents may come from teaching and research institutions in France or abroad, or from public or private research centers.
L'archive ouverte pluridisciplinaire HAL, est destinée au dépôt et à la diffusion de documents scientifiques de niveau recherche, publiés ou non, émanant des établissements d'enseignement et de recherche français ou étrangers, des laboratoires publics ou privés.

\section{(ㄷ)(1) $\$$}

Distributed under a Creative Commons Attribution - NonCommerciall 4.0 International 
1 Detection of plasmid-mediated colistin resistance, mcr-1 gene, in Escherichia coli isolated

2 from high-risk patients with acute leukemia in Spain.

3 Rym Lalaoui $^{1,2}$, Ana Djukovic ${ }^{3}$, Sofiane Bakour ${ }^{1,2}$, Jaime Sanz ${ }^{4}$, Eva M. Gonzalez-Barbera ${ }^{5}$,

4 Miguel Salavert ${ }^{5}$, Jose Luis López-Hontangas ${ }^{5}$, Miguel A. Sanz ${ }^{4}$, Karina B. Xavier ${ }^{6}$, Bernhard

5 Kuster $^{7,8}$, Laurent Debrauwer ${ }^{9}$, Carles Ubeda ${ }^{3,10}$, Jean-Marc Rolain ${ }^{1,2^{*}}$

6

7

8

$9 \quad{ }^{3}$ Centro Superior de Investigación en Salud Pública - FISABIO, Valencia, Spain.

${ }^{1}$ Aix Marseille Univ, IRD, APHM, MEPHI, Marseille, France.

${ }^{2}$ IHU-Méditerranée Infection, Marseille, France.

${ }^{4}$ Department of Medicine, Hospital Universitari i Politecnic La Fe, University of Valencia, and Centro de Investigación Biomédica en Red de Cáncer, Instituto Carlos III, Valencia, Spain.

${ }^{5}$ Hospital La Fe, Valencia, Spain.

${ }^{6}$ Instituto Gulbenkian de Ciência, Oeiras, Portugal.

${ }^{7}$ Chair of Proteomics and Bioanalytics, Technical University of Munich, Munich, Germany.

${ }^{8}$ Bavarian Center for Biomolecular Mass Spectrometry (BayBioMS), Technische Universität München, Gregor-Mendel-Strasse 4, 85354 Freising, Germany.

${ }^{9}$ Toxalim, Université de Toulouse, INRA, INP-ENVT, INP-EI-Purpan, Université de Toulouse 3 Paul Sabatier, F-31027 Toulouse, France; Axiom Platform, UMR 1331 Toxalim, MetaToul-MetaboHUB, National Infrastructure of Metabolomics and Fluxomics, F-31027 Toulouse, France.

${ }^{10}$ Centers of Biomedical Research Network (CIBER) in Epidemiology and Public Health, Madrid, Spain. 
26 MEPHI, IHU Méditerranée-Infection, 19-21 Boulevard Jean Moulin, 13385 Marseille Cedex

$27 \quad 05$

28 *Prof. Jean-Marc Rolain; Email: jean-marc.rolain@univ-amu.fr

29 Phone: (33) 486136828

30

31

Authorship statement

32 All authors meet the ICMJE authorship criteria

33

34 Abstract word count $=250$

35 Text word count $=2119$

$36 \quad$ Number of references $=24$

37 Number of tables $=2$

38 Number of figures $=0$ 


\section{Abstract}

Background: Bacterial infections in immunocompromised patients are associated with a high mortality and morbidity rate. In this high-risk group, the presence of multidrug-resistant (MDR) bacteria, particularly bacteria that harbor a transferable antibiotic resistance gene, complicates the management of bacterial infections. In this study, we investigated the presence of the transferable colistin resistance $m c r$ genes in patients with leukemia in Spain.

Methods: 217 fecal samples collected in 2013-2015 from 56 patients with acute leukemia and colonized with MDR Enterobacteriaceae strains, were screened on September 2017 for the presence of the colistin resistance $m c r$ genes $(m c r-1$ to -5$)$ by multiplex PCR. $m c r$ positive strains selected on LBJMR and MacConkey supplemented with colistin $(2 \mu \mathrm{g} / \mathrm{ml})$ media were phenotypically and molecularly characterized by antimicrobial susceptibility testing, minimum inhibitory concentration, multilocus sequence typing and plasmid characterization.

Results: Among 217 fecal samples, 5 samples collected from 3 patients were positive for the presence of the $m c r-1$ colistin-resistance gene. Four Escherichia coli strains were isolated and exhibited resistance to colistin with $\mathrm{MIC}=4 \mu \mathrm{g} / \mathrm{ml}$. Other genes conferring the resistance to $\beta$ lactam antibiotics have also been identified in $m c r-1$ positive strains, including bla TEM-206 $_{\text {and }}$ blaTEM-98. Three different sequence types were identified, including ST1196, ST140 and ST10. Plasmid characterization allowed us to detect the $m c r-1$ colistin resistance gene on conjugative IncP plasmid type.

Conclusion: To the best of our knowledge, we have identified the $m c r-1$ gene for the first time in leukemia patients in Spain. In light of these results, strict measures have been implemented to prevent its dissemination.

Keywords: Escherichia coli; colistin resistance; mcr-1 gene; leukemic patients; Spain. 


\section{Introduction}

Acute leukemia patients are considered a high-risk group because of their weakened immune system. Infections with multidrug-resistant (MDR) bacteria are highly responsive in this type of patients, mainly due to the combination of several risk factors such as: hematological disease, intensive/or repeated chemotherapy, neutropenia, healthcare-associated infections, gastrointestinal mucositis and prolonged hospitalization, which promote their colonization by this type of bacteria $[1,2]$.

Antimicrobial therapy in hematology patients, such as leukemia patients, is often used for its important contribution to the survival of these patients, but the emergence of MDR bacteria due to selection pressure complicates the management of these bacterial infections [1].

Colistin, an antibiotic long abandoned for its neurological and renal toxicity, has been reintroduced for its effectiveness against MDR Gram-negative bacteria, especially against carbapenemase producers [3, 4]. Indeed, colistin used alone or in combination with other antibiotics, has shown its effectiveness in the treatment of certain bacteremia due to MDR bacteria in hematology patients [1]. Unfortunately, since its use, colistin resistance has increased considerably, represented mainly by chromosomal gene mutations involving a variety of lipopolysaccharide (LPS) modifications [4, 5]. In 2016, Liu et al. reported for the first time colistin resistance mediated by mobile genetic elements identified in Enterobacteriaceae, called plasmid-mediated colistin resistance gene $\mathrm{mcr}-1$ [6]. Since it first detection, $m c r-1$ gene was widespread worldwide in both animals and humans, and several variants of this gene were detected in Enterobacteriaceae [7]. Very few data on PubMed are available on the occurrence of $m c r$ genes in leukemic patients and no studies have been conducted in Spain. For this reason, we have sought to detect the presence of these genes in fecal samples collected from patients with acute leukemia in a single institution in Spain. 


\section{Materials and methods}

\section{Study design}

The FloraStopMRE project (2015 Infect-ERA call) is a collaboration of a multidisciplinary consortium of scientists aiming to understand the role of the human gut microbiome in conferring protection against MDR Enterobacteriaceae infections. Between November 2013 and April 2015, a total of 802 fecal samples were collected from 133 patients with acute leukemia at the University Hospital La Fe (Valencia, Spain). All subjects gave their informed consent for inclusion before they participated in the study. The study was approved on the 1st of July 2013 by the Ethics Committee of CEIC Dirección General de Salud Pública y Centro Superior de Investigación en Salud Pública (20130515/08). Samples were collected every week during their hospitalization period. These samples were then screened for the presence of MDR Enterobacteriaceae (MRE) by plating them on Brilliance ESBL Agar (Oxoid) in order to quantify MRE levels and to study the impact of clinical factors and commensal bacteria on MRE intestinal colonization levels (results from this study will be published elsewhere). A subset of 56 patients was included in the present study. These patients had at some point been colonized by an MRE strain, and one or more consecutive samples were collected after the first MRE detection. Two hundred and seventeen samples representing the first positive MRE sample collected during a hospital admission period, plus all consecutive samples collected from this patient during this particular admission period until the MRE is no longer detected, were included in this study. Samples from 2 additional patients matching the criteria described above could not be included in this study since all the fecal material was used in a parallel study involving microbiome analysis.

\section{Microbiological tests and molecular characterization}


The 217 fecal samples were screened in September 2017 for the presence of the plasmid mediated colistin resistance $m c r$ genes (including $m c r-1,-2,-3,-4$ and -5 ) by multiplex PCR [8]. PCR positive samples $(\mathrm{N}=5)$ were cultured to isolate the colistin-resistant strains harboring $m c r$ genes by culture on LBJMR agar (containing $4 \mu \mathrm{g} / \mathrm{ml}$ colistin and $50 \mu \mathrm{g} / \mathrm{ml}$ vancomycin) and MacConkey agar supplemented with colistin $(2 \mu \mathrm{g} / \mathrm{ml})$ [9]. The isolated colonies were identified by matrix-assisted laser desorption ionization-time of flight mass spectrometry (MALDI-TOF MS) (Microflex, Bruker Daltonics, Bremen, Germany). Subsequently, the antibiotics susceptibility of the isolates was determined by evaluating the minimum inhibitory concentration (MIC) using the broth microdilution method according to the Clinical and Laboratory Standard Institute (CLSI) guidelines for the colistin antibiotic, and using Etest method on Mueller Hinton agar for the other antibiotic families tested. In addition, the ESBL (bla $a_{\mathrm{TEM}}$, bla $a_{\mathrm{SHV}}$ and $b l a_{\mathrm{CTX}-\mathrm{M}}$ ) encoding genes were screened in the colistin-resistant isolates.

\section{Molecular epidemiology}

The epidemiological relationship between the colistin resistant strains was determined by multilocus sequence typing (MLST). The seven housekeeping genes ( $a d k$, fumC, gyrB, icd, $m d h, p u r A, r e c A)$ were amplified, sequenced and then blasted on the MLST database available on the Warwick web site (http://enterobase.warwick.ac.uk/species/ecoli/allele_st_search).

\section{Conjugation experiments and plasmid analysis}

Conjugative experiments were conducted using azide-resistant Escherichia coli J53 as a recipient, as described [10]. The transconjugants were selected on Luria Bertani (LB) agar (Beckton Dickinson, Le Pont de Claix, France) supplemented with sodium azide $(120 \mu \mathrm{g} / \mathrm{ml})$ and colistin $(2 \mu \mathrm{g} / \mathrm{ml})$. Transconjugant strains were screened for the presence of the colistin 
resistance genes ( $m c r$ genes) by PCR, and were subjected to antibiotic susceptibility testing as described above. Plasmid typing experiments were conducted on transconjugant strains using standard PCR [11].

\section{Results}

\section{Microbiological, molecular and epidemiological characterization}

Five of the 217 fecal samples tested were positive for the presence of the mcr- 1 gene variant. The PCR product sequence showed $100 \%$ identity to the published sequence [3]. These samples corresponded to three patients with acute myeloid leukemia (AML) named Patient-1 (two positive samples), Patient-2 (one positive sample) and Patient-3 (two positive samples) aged 59, 48 and 63 years respectively (Table 1). All patients received an antimicrobial therapy prior sampling, including ciprofloxacin, piperacillin, meropenem, vancomycin and teicoplanin, but none had received colistin (Table 1). The patients also been subjected to either chemotherapy, transplant or both. Patient-1 received two chemotherapy and one bone marrow transplant prior sampling the two $m c r-1$ positive samples, unlike the positive $m c r-1$ sample from Patient-2 was collected while the patient showed clinical signs of infection and after undergoing bone marrow transplantation. During chemotherapy treatment of the Patient3, the two mcr-1 positive samples were collected. The culture method allowed us to isolate four E. coli strains among the five $m c r-1$ positive samples; two strains from Patient-1 (E. coli643 and E. coli-648), one strain from Patient-2 (E. coli-866) and one strain from Patient-3 (E. coli-913). The E. coli strains isolated were resistant to at least five antibiotics among the sixteen tested, including colistin with $\mathrm{MIC}=4 \mu \mathrm{g} / \mathrm{ml}$ (Table 1$)$. The four colistin resistant $E$. coli carried the $m c r-1$ gene also harbored ESBL genes, including bla ${ }_{\mathrm{TEM}-206}$ and bla $_{\mathrm{TEM}-98}$ (Table 1). 
According to the MLST analysis, three different sequence types (STs) were assigned to the four E. coli isolates, including ST1196, ST140 and ST10. E. coli-643 and E. coli-648 strains retrieved from Patient-1 belonged to the same sequence type, ST1196.

\section{Conjugation experiments and plasmid analysis}

Conjugation experiment was conducted on the three $E$. coli harboring $m c r-1$, including $E$. coli-643, E. coli-866 and E. coli-913. The E. coli-648, considered a duplicate of Patient-1 E. coli strain, was not included in this experiment. Conjugative experiment allowed us to isolate 3 transconjugants (E. coli J53-643 Azide ${ }^{\mathrm{r}}$, E. coli J53-866 Azide ${ }^{\mathrm{r}}$ and E. coli J53-913 Azide ${ }^{\mathrm{r}}$ ) resistant to colistin with $\mathrm{MIC}=4 \mu \mathrm{g} / \mathrm{ml}$. The antibiotic susceptibility profile of these transconjugant strains is presented in Table 2. All transconjugant strains were positive to the mcr-1 gene and the plasmid typing showed that this gene was located on IncP plasmid.

\section{Discussion}

Antibiotic resistance in immunocompromised patients was mainly represented by the Grampositive cocci group, such as methicillin-resistant Staphylococcus aureus (MRSA) and vancomycin-resistant Enterococcus (VRE). In the last decades, the emergence of infections due to Gram-negative bacteria, especially Enterobacteriaceae and Pseudomonas, has been noted [12]. The Gram-negative bacilli identified as the predominant infectious agent in hematological patients is E. coli. In this group of patients, E. coli most often exhibits a high rate of resistance to quinolones, ceftazidime and beta-lactam antibiotics [12]. These results have been observed in our study where the $E$. coli strains, isolated from our patients with acute leukemia, in addition to other antibiotics, also exhibited resistance to beta-lactam and quinolones.

To counter the emergence of MDR bacteria in hematological patients, the use of colistin as monotherapy or in combination with other antibiotics, such as beta-lactams, aminoglycosides, 
tigecycline or fosfomycin, has been suggested by the current American and European guidelines on febrile neutropenia [1]. Unfortunately, since its use in clinical settings, colistin resistance has increased and this is becoming very alarming, especially since the detection of a plasmid containing the $m c r-1$ colistin resistance gene [6]. The result that emerged in our study and which worried us was the fact that we isolated from the leukemia patients $E$. coli strains resistant not only to the antibiotics mentioned above but also to the antibiotic of last resort, colistin, due to the presence of the $m c r-1$ gene.

The colistin resistance $m c r-1$ gene has been reported worldwide, mainly in animals [4]. In Spain, the $m c r-1$ gene has also been identified in animals (poultry, pigs and swine) $[13,14]$, in the environment (wastewater and sewage water) $[15,16]$ and a few studies reported the $m c r-1$ gene in clinical isolates (urine, blood, sputum) [4]. In patients with leukemia, the colistinresistance $m c r-1$ variant has been reported in five studies over the world including China, Austria and Italy. This gene was mostly detected in E. coli strains followed by Klebsiella pneumoniae and conferred to these strains a resistance to colistin with MIC ranging from 4 to $8 \mu \mathrm{g} / \mathrm{ml}$ [17-21]. This was reported in our study, where the colistin resistance $\mathrm{mcr}-1$ gene was detected in $E$. coli strains resistant to colistin with $\mathrm{MIC}=4 \mu \mathrm{g} / \mathrm{ml}$ in high-risk patients with a weak immune system, who are leukemia patients, in Spain.

Concerning the genetic support of colistin resistance, the $m c r-1$ gene was generally identified in different plasmid types such as IncI2, IncHI2, IncX4 and IncP [22]. In our strains, the $m c r$ 1 gene was located on IncP transferable plasmid type. In Spain, the IncP plasmid type has been previously reported to be associated with different resistance genes, such as carbapenem resistant genes [23], but has never been associated with the $m c r-1$ gene.

Worldwide, different sequence types of E. coli harboring the $m c r-1$ gene have been detected in leukemia patients such as ST10, ST46, ST58, ST156, ST607 and ST3944 [19-21]. ST10 has made a significant contribution to the dissemination of the mcr-1 gene worldwide [22]. In 
our study, the ST10 was reported in only one strain. ST1196 was the predominant sequence type detected in our strains (2 out of 4 ). This ST was reported in only one study in which the mcr-1 positive E. coli strain was recovered from a wastewater treatment plant at West China Hospital [24]. In addition, our study reports for the first time the association of E. coli ST140 with the presence of the $m c r-1$ gene. Unfortunately, the lack of information on the history of patients; if they have been hospitalized, if they have travelled to a high-risk country where the $m c r-1$ gene is endemic or if the patient has been in contact with animals, does not allow us to determine the epidemiology and origin of the $m c r-1$ gene detected in our study.

In the present study, we detected the plasmid-mediated colistin resistance $m c r-1$ gene in patients not treated with colistin who were hospitalized between 2013 and 2015 at $\mathrm{La} \mathrm{Fe}$ University Hospital. This suggests that the appearance of the $m c r-1$ gene in these patients was not due to selection pressure with this antibiotic. Despite the fact that our $m c r-1$ positives $E$. coli strains do not exhibit resistance to all the antibiotics tested, the detection of the $\mathrm{mcr}-1$ gene on transferable plasmid is alarming. Indeed, the worrying scenarios emerging from this study are the acquisition of the plasmid encoding $m c r-1$ genes by MDR bacteria in these leukemia patients whose immune systems are already weakened, and the transmission of these resistant bacteria from one patient to another. This situation can lead the clinician into therapeutic impasse. This is exactly what was reported in a study conducted by Di Pilato et al. where the $m c r-1$ gene was identified in an MDR KPC-producing K. pneumoniae ST512 [21]. In these cases, what measures should be taken to prevent the spread of colistin resistance in this high-risk population? In our situation, the isolation of patients with $m c r$ genes encoding colistin resistance could be an urgent solution to avoid any risk of transmission of such genes to other immunocompromised patients. In the long-term, the implementation of rapid tests to detect antibiotic resistance genes and the systematic screening of the carrying of antibiotic 
229 resistance genes as soon as they arrive at the hospital, would be a great solution for controlling the spread of antibiotic resistance genes and thus avoid any therapeutic impasse. 
232 The authors thank Linda Hadjadj for her technical assistance.

233 The authors also thank CookieTrad for proofreading the text.

234 Conflict of interests

235 The authors declare they have no conflicts of interest

236 Funding source

237 This work was supported by the ANR FloraStopInfectMRE project, InfecERA-ERANET-

238 Acciones complementarias (PCIN-2015-094) to CU and by IHU Méditerranée Infection,

239 Marseille, France and by the French Government under the «Investissements d'avenir»

240 (Investments for the Future) proGram managed by the Agence Nationale de la Recherche

241 (ANR, fr: National Agency for Research), (reference: Méditerranée Infection 10-IAHU- 03).

242 This work was supported by Région Provence Alpes Côte d'Azur and European funding

243 FEDER PRIMI. 


\section{References}

245

246

247

248

249

250

251

252

253

254

255

256

257

258

259

260

261

262

263

264

265

266

267

[1] Trubiano JA, Worth LJ, Thursky KA, Slavin MA. The prevention and management of infections due to multidrug resistant organisms in haematology patients. Br J Clin Pharmacol 2015;79(2):195-207. https://doi.org/10.1111/bcp.12310.

[2] Alp S, Akova M. Antibacterial resistance in patients with hematopoietic stem cell transplantation. Mediterr J Hematol Infect Dis 2017;9(1):e2017002. https://doi.org/10.4084/mjhid.2017.002.

[3] Olaitan AO, Li J. Emergence of polymyxin resistance in Gram-negative bacteria. Int J Antimicrob Agents 2016;48(6):581-2. https://doi.org/10.1016/j.ijantimicag.2016.11.003. [4] Baron S, Hadjadj L, Rolain JM, Olaitan AO. Molecular mechanisms of polymyxin resistance: knowns and unknowns. Int J Antimicrob Agents 2016;48(6):583-91. https://doi.org/10.1016/j.ijantimicag.2016.06.023.

[5] Olaitan AO, Morand S, Rolain JM. Mechanisms of polymyxin resistance: acquired and intrinsic resistance in bacteria. Front Microbiol 2014;5:643.

https://doi.org/10.3389/fmicb.2014.00643.

[6] Liu YY, Wang Y, Walsh TR, Yi LX, Zhang R, Spencer J, et al. Emergence of plasmidmediated colistin resistance mechanism MCR-1 in animals and human beings in China: a microbiological and molecular biological study. Lancet Infect Dis 2016;16(2):161-8. https://doi.org/10.1016/S1473-3099(15)00424-7.

[7] Wang X, Wang Y, Zhou Y, Li J, Yin W, Wang S, et al. Emergence of a novel mobile colistin resistance gene, $m c r-8$, in NDM-producing Klebsiella pneumoniae. Emerg Microbes Infect 2018;7(1):122. https://doi.org/10.1038/s41426-018-0124-Z.

[8] Rebelo AR, Bortolaia V, Kjeldgaard JS, Pedersen SK, Leekitcharoenphon P, Hansen IM, et al. Multiplex PCR for detection of plasmid-mediated colistin resistance determinants, $\mathrm{mcr}$ - 
1, $m c r-2, m c r-3, m c r-4$ and $m c r-5$ for surveillance purposes. Euro Surveill 2018;23(6). https://doi.org/10.2807/1560-7917.ES.2018.23.6.17-00672.

[9] Bardet L, Le Page S, Leangapichart T, Rolain JM. LBJMR medium: a new polyvalent culture medium for isolating and selecting vancomycin and colistin-resistant bacteria. BMC Microbiol 2017;17(1):220. https://doi.org/10.1186/s12866-017-1128-x.

[10] Bachiri T, Lalaoui R, Bakour S, Allouache M, Belkebla N, Rolain JM, et al. First report of the plasmid-mediated colistin resistance gene mcr-1 in Escherichia coli ST405 isolated from wildlife in Bejaia, Algeria. Microb Drug Resist 2017;24(7):890-5. https://doi.org/10.1089/mdr.2017.0026.

[11] Carattoli A, Bertini A, Villa L, Falbo V, Hopkins KL, Threlfall EJ. Identification of plasmids by PCR-based replicon typing. J Microbiol Methods 2005;63(3):219-28. https://doi.org/10.1016/j.mimet.2005.03.018.

[12] Blennow O, Ljungman P. The challenge of antibiotic resistance in haematology patients. Br J Haematol 2016;172(4):497-511. https://doi.org/10.1111/bjh.13816.

[13] Quesada A, Ugarte-Ruiz M, Iglesias MR, Porrero MC, Martínez R, Florez-Cuadrado D, et al. Detection of plasmid mediated colistin resistance (MCR-1) in Escherichia coli and Salmonella enterica isolated from poultry and swine in Spain. Res Vet Sci 2016;105:134-5. https://doi.org/10.1016/j.rvsc.2016.02.003.

[14] Poirel L, Kieffer N, Fernandez-Garayzabal JF, Vela AI, Larpin Y, Nordmann P. MCR-2mediated plasmid-borne polymyxin resistance most likely originates from Moraxella pluranimalium. J Antimicrob Chemother 2017;72(10):2947-9. https://doi.org/10.1093/jac/dkx225.

[15] Lekunberri I, Balcázar JL, Borrego CM. Detection and quantification of the plasmidmediated $m c r-1$ gene conferring colistin resistance in wastewater. Int J Antimicrob Agents 2017;50(6):734-6. https://doi.org/10.1016/j.ijantimicag.2017.08.018. 
[16] Ovejero CM, Delgado-Blas JF, Calero-Caceres W, Muniesa M, Gonzalez-Zorn B.

Spread of $m c r$ - 1 -carrying Enterobacteriaceae in sewage water from Spain. J Antimicrob Chemother 2017;72(4):1050-3. https://doi.org/10.1093/jac/dkw533.

[17] Zhang R, Dong N, Huang Y, Zhou H, Xie M, Chan EW, et al. Evolution of tigecyclineand colistin-resistant CRKP (carbapenem-resistant Klebsiella pneumoniae) in vivo and its persistence in the GI tract. Emerg Microbes Infect. 2018;7(1):127. https://doi.org/10.1038/s41426-018-0129-7.

[18] Tietgen M, Semmler T, Riedel-Christ S, Kempf VAJ, Molinaro A, Ewers C, et al. Impact of the colistin resistance gene $m c r-1$ on bacterial fitness. Int J Antimicrob Agents 2018;51(4):554-61. https://doi.org/10.1016/j.ijantimicag.2017.11.011.

[19] Tian GB, Doi Y, Shen J, Walsh TR, Wang Y, Zhang R, et al. MCR-1-producing Klebsiella pneumoniae outbreak in China. Lancet Infect Dis 2017;17(6):577. https://doi.org/10.1016/S1473-3099(17)30266-9.

[20] Hartl R, Kerschner H, Lepuschitz S, Ruppitsch W, Allerberger F, Apfalter P. Detection of the $m c r-1$ Gene in a Multidrug-Resistant Escherichia coli Isolate from an Austrian Patient. Antimicrob Agents Chemother 2017;61(4). pii: e02623-16. https://doi.org/10.1128/aac.02623-16.

[21] Di Pilato V, Arena F, Tascini C, Cannatelli A, Henrici De Angelis L, Fortunato S, et al. mcr-1.2, a New mor Variant Carried on a Transferable Plasmid from a Colistin-Resistant KPC Carbapenemase-Producing Klebsiella pneumoniae Strain of Sequence Type 512. Antimicrob Agents Chemother 2016;60(9):5612-5. https://doi.org/10.1128/AAC.01075-16.

[22] Hadjadj L, Riziki T, Zhu Y, Li J, Diene SM, Rolain JM. Study of $m c r-1$ gene-mediated colistin resistance in Enterobacteriaceae isolated from humans and animals in different countries. Genes (Basel) 2017;8(12). pii: E394. https://doi.org/10.3390/genes8120394. 
317 [23] Yao Y, Lazaro-Perona F, Falgenhauer L, Valverde A, Imirzalioglu C, Dominguez L, et

318 al. Insights into a novel bla $a_{\mathrm{KPC}-2}$-encoding IncP-6 plasmid reveal carbapenem-resistance

319 circulation in several Enterobacteriaceae species from wastewater and a hospital source in

320 Spain. Front Microbiol 2017;8:1143. https://doi.org/10.3389/fmicb.2017.01143.

321 [24] Zhao F, Feng Y, Lü X, McNally A, Zong Z. Remarkable diversity of Escherichia coli

322 carrying $m c r-1$ from hospital sewage with the identification of two new $m c r-1$ variants. Front

323 Microbiol 2017;8:2094. https://doi.org/10.3389/fmicb.2017.02094. 
324 Table 1. Characterization of samples and strains harboring the $m c r-1$ gene identified in leukemia patients in Spain.

\begin{tabular}{|c|c|c|c|c|c|c|c|c|c|c|}
\hline Patients & Samples & $\begin{array}{l}\text { Sampling } \\
\text { date }\end{array}$ & $\begin{array}{c}\text { Antimicrobial } \\
\text { therapy }\end{array}$ & $\begin{array}{l}\text { Strains } \\
\text { mcr-1 }\end{array}$ & $\begin{array}{l}\text { MIC colistin } \\
(\mu \mathrm{g} / \mathrm{ml})\end{array}$ & $\begin{array}{c}\text { Resistant } \\
\text { AST phenotype }\end{array}$ & ESBL genes & ST & $\begin{array}{c}\text { Conjugation } \\
\text { experiment }\end{array}$ & $\begin{array}{c}\text { Plasmid } \\
\text { Typing }\end{array}$ \\
\hline \multirow{2}{*}{ Patient-1 } & 643 & $06 / 11 / 2014$ & $\begin{array}{c}\text { MEM, TZP, CIP, } \\
\text { VAN }\end{array}$ & E. coli- 643 & (ro & $\begin{array}{c}\text { AMX, AMC, CEF, } \\
\text { CIP, CST, SXT, } \\
\text { DOX }\end{array}$ & bla ${ }_{\mathrm{TEM}-206}$ & 1196 & - 10 & IncP \\
\hline & 648 & $12 / 11 / 2014$ & $\begin{array}{c}\text { MEM, TZP, CIP, } \\
\text { VAN }\end{array}$ & E. coli- 648 & 4 & $\begin{array}{c}\text { AMX, AMC, CEF, } \\
\text { CIP, CST, SXT, } \\
\text { DOX }\end{array}$ & $b l a_{\text {TEM-206 }}$ & 1196 & Not tested & Not tested \\
\hline Patient-2 & 866 & $11 / 03 / 2015$ & MEM, TEC, TZP & E. coli-866 & 4 & $\begin{array}{c}\text { AMX, AMC, CST, } \\
\text { SXT, DOX }\end{array}$ & bla & 140 & + & IncP \\
\hline \multirow{2}{*}{ Patient-3 } & 913 & $29 / 03 / 2015$ & CIP, TZP & E. coli-913 & 4 & $\begin{array}{l}\text { AMX, AMC, CEF, } \\
\text { CIP, CST, DOX }\end{array}$ & $b l a_{\mathrm{TEM}-98}$ & 10 & + & IncP \\
\hline & 923 & $01 / 04 / 2015$ & CIP, TZP & $\begin{array}{l}\text { No bacteria } \\
\text { isolated }\end{array}$ & I & 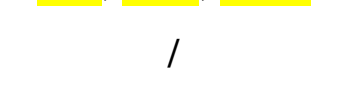 & I & l & I & l \\
\hline
\end{tabular}

325 AMX ; Amoxicillin, AMC ; Amoxicillin/clavulanic acid, CEF ; Cephalothin, CIP ; Ciprofloxacin, SXT ; Trimethoprim-sulfamethoxazole,

326 DOX ; Doxycycline, CST ; Colistin, MEM ; Meropenem, TZP ; Piperacillin-tazobactam, VAN ; Vancomycin, TEC ; Teicoplanin.

327 MIC: Minimum Inhibitory Concentration, AST: Antimicrobial Susceptibility Testing, ESBL: Extended Spectrum $\beta$-lactamase, ST: Sequence

328 Type. 
Table 2. Antibiotic susceptibility of E. coli strains harboring $m c r-1$ gene and their transconjugants ${ }^{\mathrm{a}}$.

\begin{tabular}{|c|c|c|c|c|c|c|c|}
\hline \multirow{2}{*}{ Antibiotic(s) tested } & \multicolumn{7}{|c|}{ Minimum Inhibitory Concentration $(\mu \mathrm{g} / \mathrm{ml})$} \\
\hline & E. coli J53 & E. coli-643 & E. coli J53-643 Azider & E. coli-866 & E. coli J53-866 Azide ${ }^{r}$ & E. coli-913 & E. coli J53-913 Azide \\
\hline Amoxicillin & $4(S)$ & $\geq 256(\mathrm{R})$ & $\geq 256(\mathrm{R})$ & $\geq 256(\mathrm{R})$ & $\geq 256(\mathrm{R})$ & $\geq 256(\mathrm{R})$ & $\geq 256(\mathrm{R})$ \\
\hline Amoxicillin-clavulanate & $3(\mathrm{~S})$ & $12(\mathrm{R})$ & $8(\mathrm{R})$ & $12(\mathrm{R})$ & $8(\mathrm{R})$ & $8(\mathrm{R})$ & $3(\mathrm{~S})$ \\
\hline Piperacillin-tazobactam & $1(\mathrm{~S})$ & $4(\mathrm{~S})$ & $1.5(\mathrm{~S})$ & $0.75(\mathrm{~S})$ & $0.75(\mathrm{~S})$ & $2(\mathrm{~S})$ & $1(\mathrm{~S})$ \\
\hline Ceftriaxone & $0.047(\mathrm{~S})$ & $0.047(\mathrm{~S})$ & $0.023(\mathrm{~S})$ & $0.032(\mathrm{~S})$ & $0.016(\mathrm{~S})$ & $0.064(\mathrm{~S})$ & $0.047(\mathrm{~S})$ \\
\hline Cefepime & $0.064(\mathrm{~S})$ & $0.25(\mathrm{~S})$ & $0.047(\mathrm{~S})$ & $0.032(\mathrm{~S})$ & $0.032(\mathrm{~S})$ & $0.064(\mathrm{~S})$ & $0.047(\mathrm{~S})$ \\
\hline Ertapenem & $0.004(\mathrm{~S})$ & $0.008(\mathrm{~S})$ & $0.003(\mathrm{~S})$ & $0.002(\mathrm{~S})$ & $0.002(\mathrm{~S})$ & $0.004(\mathrm{~S})$ & $0.004(\mathrm{~S})$ \\
\hline Imipenem & $0.19(\mathrm{~S})$ & $0.125(\mathrm{~S})$ & $0.094(\mathrm{~S})$ & $0.125(\mathrm{~S})$ & $0.094(\mathrm{~S})$ & $0.125(\mathrm{~S})$ & $0.125(\mathrm{~S})$ \\
\hline Amikacin & $0.5(\mathrm{~S})$ & $2(\mathrm{~S})$ & $1.5(\mathrm{~S})$ & $1.5(\mathrm{~S})$ & $1.5(\mathrm{~S})$ & $2(\mathrm{~S})$ & $0.5(\mathrm{~S})$ \\
\hline Ciprofloxacin & $0.016(\mathrm{~S})$ & $\geq 32(\mathrm{R})$ & $0.008(\mathrm{~S})$ & $0.008(\mathrm{~S})$ & $0.006(\mathrm{~S})$ & $\geq 32(\mathrm{R})$ & $0.023(\mathrm{~S})$ \\
\hline Doxycycline & $0.5(\mathrm{~S})$ & $24(\mathrm{R})$ & $6(\mathrm{~S})$ & $8(\mathrm{R})$ & $8(\mathrm{R})$ & $12(\mathrm{R})$ & $6(\mathrm{~S})$ \\
\hline Fosfomycin & $0.38(\mathrm{~S})$ & $4(S)$ & $4(S)$ & $6(\mathrm{~S})$ & $4(\mathrm{~S})$ & $3(\mathrm{~S})$ & $0.75(\mathrm{~S})$ \\
\hline $\begin{array}{l}\text { Trimethoprim- } \\
\text { sulfamethoxazole }\end{array}$ & $0.012(\mathrm{~S})$ & $\geq 32(\mathrm{R})$ & $\geq 32(\mathrm{R})$ & $\geq 32(\mathrm{R})$ & $\geq 32(\mathrm{R})$ & $0.012(\mathrm{~S})$ & $0.012(\mathrm{~S})$ \\
\hline Colistin & $0.125(\mathrm{~S})$ & $4(\mathrm{R})$ & $4(\mathrm{R})$ & $4(\mathrm{R})$ & $4(\mathrm{R})$ & $4(\mathrm{R})$ & $4(\mathrm{R})$ \\
\hline
\end{tabular}

$330{ }^{\mathrm{a}}$ Antibiotic susceptibility testing was performed according to EUCAST recommendations.

$331 \mathrm{~S}$; susceptible, R; resistant. 